\title{
RANA PISMENOST - VRIJEDNOST PROCJENE
}

\author{
MIRJANA LENČEK ${ }^{1}$, MARTINA UŽAREVIĆ ${ }^{2}$ \\ ${ }^{1}$ Odsjek za logopediju, Edukacijsko-rehabilitacijski fakultet, Sveučilišta u Zagrebu, mlencek@erf.hr \\ ${ }^{2}$ Gojanec, Ulica Ljudevita Gaja 34, 42000 Varaždin, martina.simek1211@gmail.com
}

Primljeno: 8.10.2016.

Izvorni znanstveni rad

Prihvaćeno: 28.11.2016.

UDK: 159.946.4-053.4

Sažetak: Istraživanja rane pismenosti različito određuju doprinos fonološke svjesnosti, poznavanja slova, koncepta o tisku, govornog jezika, rječnika, narativnih sposobnosti, rukopisnih vještina i drugih predviđatelja za kasniji uspjeh u čitanju, pisanju, ali $i$ akademskom napredovanju u cjelini. U Hrvatskoj nema sustavnijih istraživanja i praćenja razvoja ovih pokazatelja kao niti točno definiranih kurikuluma predškolskog odgoja i obrazovanja koji bi osigurali poučavanje znanjima neophodnima za kasniju formalnu pismenost. Pilot ispitivanjem trogodišnje i četverogodišnje djece (koja pohađaju vrtićke programe) uporabom materijala koji je sadržavao Upitnik za procjenu rane pismenosti i podtestove PredČip testa Fonološka svjesnost $i$ Imenovanje slova, prikupljeni su podaci o razini rane pismenosti ispitane djece. Dobiveni rezultati pokazuju da, sukladno očekivanjima, djeca starije kronološke dobi imaju više znanja o konceptu tiska, uspješnija su na zadacima fonološke svjesnosti i imenovanja slova te imaju bolje grafomotoričke vještine. Nisu pronađene statistički značajne razlike između trogodišnjaka i četverogodišnjaku na skupnoj varijabli Izranjajuće čitanje i pisanje, a koja se temelji na prepoznavanju obilježja pisane riječi i predvještinama pisanja. Postignuća ispitane djece uspoređena su i s očekivanim rezultatima i normama unutar drugih jezika i pisama kako bi se potakla nastojanja za promišljanjem kriterija i načina poučavanja rane pismenosti. Istraživanje pokazuje da ispitani segmenti rane pismenosti - koncept o tisku, izranjajuća pismenost, precrtavanje, fonološka svjesnost i imenovanje slova mogu biti osnova za prepoznavanje djece rizične za nastanak teškoća u čitanju i pisanju i djece s disleksijom. Rezultati pojedinaca prikupljeni prema navedenim segmentima rane pismenosti mogu, u slučajevima niskih postignuća ili odstupanja, biti osnova za izradu intervencijskih programa, a za što su potrebne i kvalitativne analize rezultata. Kvalitativna analiza rezultata prema dobnoj pripadnosti pokazala je da slijed težina, odnosno uspješnosti u rješavanju zadataka nije posve jednak kod trogodišnjaka u odnosu na četverogodišnjake. To upućuje na mogućnost da postoji dobno neujednačeni razvoj ispitanih vještina bilo iz razloga drugačijih uvjeta sazrijevanja ili značajnijeg udjela poučavanja za neku određenu vještinu. Veći uzorak ispitanika i provjerene mjerne karakteristike materijala mogle bi osigurati bolji uvid u ranu pismenost.

Ključne riječi: rana pismenosti, koncept o tisku, fonološka svjesnost, poznavanje slova

\section{UVOD}

\section{Pismenost(i) - rana pismenost}

Pojam pismenosti prisutan je u literaturi koja je usmjerena na fenomene čitanja, pisanja i disleksije još od devedesetih godina prošloga stoljeća. Određenje pismenosti, premda se nerijetko čini lako razumljivim i prihvaća sa stajališta „,biti pismen ili biti nepismen", složen je i dinamičan koncept koji se mijenja pod utjecajem znanstvenih istraživanja, institucionalnih pristupa, nacionalnog konteksta, kulturoloških promjena i osobnih iskustava. Još 1987. UNESCO predlaže definiciju: Osoba je pismena ako može s razumijevanjem napisati i pročitati jednostavnu rečenicu o svom svakodnevnom životu. Ovakvim se određenjem čitanje i pisanje ističu kao najvažnije vještine pismenosti. Čitalačka pismenost uključuje skup vještina i sposobnosti za korištenje pisanog jezika u komunikaciji, zabavi, obrazovanju (Wildová i Kropáčková, 2015). Poznavanje čitanja, pisanja, a čemu niz autora dodaje i poznavanje računanja (što se i tradicionalno unosi u određenje pismenosti), može se uvrstiti u domenu primarne pismenosti. Društva koja brinu o razini pismenosti, smatrajući da je ona ključna za socijalni i ekonomski napredak pojedinca i društva (Purcell-Gates i Tierney, 2009), funkcioniraju po principu ,stvoriti preduvjete“, odnosno pripremiti se za usvajanje čitanja i pisanja, za razliku od društava bez preduvjeta kojima preostaje paradigma ,popravljati“" ono što nije učinjeno kroz ranu pismenost. U kontekst oblikovanja dobrih preduvjeta pismenosti uključene su i zakonske odredbe poput npr. razine predškolskog obrazo- 
vanja s programom poticanja rane pismenosti koji se temelje na nizu podataka - od podataka studija mozgovnog razvoja, vrednovanja postojećih predškolskih programa do podataka o iskustvima djece s kasnijim dobrim akademskim uspjehom (Report The Standing Senate Committee on Social Affairs, Science and Technology, Canada, 2009). Kod nas u Hrvatskoj postoji Zakon o predškolskom odgoju i obrazovanju (NN 94/13, Članak 23.a) kojim program predškole (poznatiji kao „mala škola“) postaje obvezan za svu djecu u godini prije polaska u osnovnu školu, no sadržaj programa još nije jasno definiran pa je način provedbe zapravo prepušten znanju i motiviranosti odgojitelja (Peretić, Padovan, Kologranić Belić, 2015). Sadržaji koje bi program trebao obuhvatiti, trebaju se oslanjati na istraživačke i stručne studije u polju rane pismenosti kojih kod nas nema dovoljno.

Pojam rane pismenosti među prvima upotrebljava Clay (1966 prema Whitehurst i Lonigan, 1998). Jednostavno određenje daje Scarborough (2001): rana pismenost odnosi se na preduvjete - sposobnosti i vještine bitne za ovladavanje čitanjem, a koje dijete stječe rano u životu, prije nego što započne formalni oblik poduke. Ovaj konstrukt veže se uz jezik i uz tisak (prema Smidt i sur., 2012). Mjere koje unutar jezika pripadaju ranoj pismenosti nisu istovjetne za niz autora (Scarborough, 1998; Snowling i sur., 2000; Molfese i sur. 2008; Kuvač Kraljević i Lenček, 2012; Pinto i sur.,2012). Temeljno su one vezane uz opće jezične vještine i znanja, fonološku svjesnost, rječnik, naraciju i poznavanje slova - komponentu koju jezik zapravo dijeli s mjerama tiska i koju neki autori (poput Caspe,2009) svrstavaju u mjere tiska. Mjere tiska odnose se na koncept tiska - konvencije koje se mogu razumjeti i bez čitanja, kao npr. da se čita s lijeva na desno, razumijevanje postojanja i značenja interpunkcije i slično, te na motivaciju za tisak - interes djeteta da mu se čita. Ranu pismenost čini i izranjajuće čitanje i pisanje - pretvaranje djeteta da čita i piše; mogućnost da globalno zahvaća i pročita poznate natpise iz okoline te piše pojedinačna slova (Whitehurst i Lonigan, 1998). Sve ove mjere, uz osobite kognitivne čimbenike (poput npr. fonološkog radnog pamćenja i brzog imenovanja) temelj su prijelaza i osnova ulaska u konvencionalno čitanje i pisanje (Justice i Kaderavek, 2004).
Određenje/definicije rane pismenosti i niz istraživanja sposobnosti i vještina koje su uključene $\mathrm{u}$ ranu pismenost daju smjernice za oblikovanje materijala za testiranje, procjenu, a onda i zaključivanje o razini rane pismenosti kod pojedinaca, kod manjih i većih grupa te populacije u cjelini. Provjere rane pismenosti ostvaruju se kroz neformalne i formalne načine i uključuju materijale utemeljene na tehnikama i postupcima s univerzalnim kriterijima (npr. slijed razvoja fonološke svjesnosti (Goswami, 2002; Antony i Francis, 2005; Lenček i Ivšac Pavliša 2011)), ali i one u kojima su izražene osobitosti jezika i pisma i u kojima je uvažavana ortografska transparentnost (Georgiou i sur., 2012; Ziegler i sur.; 2010). Tako primjerice u Engleskoj postoji standardizirani test namijenjen petogodišnjacima (Fletcher i Lyon, 1998), a u Japanu se provodi niz testiranja rane pismenosti vezano uz mogućnosti pohađanja prestižnih škola (Tolbert, 1999 prema Johnston i Rogers, 2003). Procjene spremnosti za čitanje i pisanje u SAD postoje od tridesetih godina prošlog stoljeća (Morphet i Washburn; 1932; Gates, 1937, prema Johnston i Rogers, 2003), uz neprestano mijenjanje paradigme prema rezultatima istraživačkih i kliničkih ispitivanja relevantnih za ovo područje. Aktualna paradigma usmjerava se na procjenu, praćenje i poticanje rane pismenosti zbog: (1) značajnog udjela rane pismenosti u kasnijem akademskom uspjehu (Scarborough, 2009); (2) potrebe otkrivanja djece s rizikom za nastanak teškoća u čitanju i pisanju, odnosno za disleksiju, a u smislu prevencije kasnijih teškoća (Catts i sur., 2009), za što su oblikovani i posebni testovi (npr. DIBELS/Good i Kaminski, 2003, prema Goffreda, Diperna i Pedersen, 2009; PELI; Abbott i sur., prema Kaminski i sur.,2014) i (3) prepoznavanja vrijednosti programa ranog poticanja i rane intervencije (Rachmani, 2011; Hall i sur., 2015; Dennis, 2016). I zemlje (društva) s visokim postignućima na provjerama školske pismenosti i razine obrazovnih postignuća, kao što su Hong Kong, Finska, Danska, Singapur (PISA ili PIRLS testiranja) temelje svoja shvaćanja o vrijednosti procjene rane pismenosti na navedena tri aspekta (Torppa i sur., 2010; Li i Rao, 2005; Clasen, 2016). Zajednička su im i shvaćanja fenomena vrijednosti rane dobi, posebno 3 do 6 godina, za proces cjeloživotnog obrazovanja i uvažavanje spoznaje o nenadoknadivosti pojedinih vještina iz 
tog ranog razdoblja za učenja koja slijede (Wildova i Kropačkova, 2015).

U Hrvatskoj postoje pozitivni pomaci i napredak u razumijevanju vrijednosti pojedinih aspekata rane pismenosti (i rane dobi općenito) za kasnije obrazovanje, no oni nisu rezultat sustavnih politika koje bi ih promicale, već sporadičnih napora koji su nerijetko ishod strukovnih ili građanskih poticaja i istraživačkih aktivnosti (Lenček, 1995; Kolić Vehovec, 2003; Ščapec i Kuvač Kraljević, 2013; Lenček, Kolundžić i Arapović, 2012; Ivšac Pavliša i Lenček, 2011). Razmatrajući osnove za procjenu rane pismenosti, vidljivo je da unutar hrvatskog jezika postoje prevedeni i prilagođeni materijali za procjenu jezično-govornog razvoja te je oblikovan i test predvještina čitanja - PredČip test (Kuvač Kraljević i Lenček, 2012). Trijažni test PredČip sadrži značajan dio informacija koje procjenjuje i većina stranih testova rane pismenosti, no ne uključuje dijelove poput svjesnosti o tisku i vizualnog rječnika. U spomenutim okruženjima i zemljama koje promiču vrijednost pismenosti postoje dobni miljokazi ili točni podaci o razinama za navedene pokazatelje rane pismenosti (Justice, Invernizzi i Meier, 2002). Većinom su definirani na razini različitih državnih organizacija, odjela i službi koje brinu o ranom dječjem razvoju (npr. američki Louisiana Department of Education; 2013; Office of Early Learning in Florida, 2011; House i sur., 2013) kao i unutar pomno razrađenih predškolskih kurikuluma kao dijelova nacionalnih strategija odgoja i obrazovanja, kao što je to u Velikoj Britaniji i Novom Zelandu (prema Soler i Miller, 2003).

Premda je glavnina navedenih spoznaja o vrijednosti rane pismenosti prihvaćena u Hrvatskoj, mali je broj istraživačkih radova u ovom području kako zbog priznavanja jezika, tako i zbog nedostatka mjernih instrumenata, usmjerenosti na školsku dob kao ključnu za pismenost i nedostatno povezivanje rane dobi i kasnijeg akademskog ishoda.

Upravo stoga je namjera ovog rada dobivanje uvida $u$ razinu pismenosti djece rane predškolske dobi uporabom materijala koji uključuje veći broj mjera rane pismenosti. Pilot istraživanje provedeno je na trogodišnjoj i četverogodišnjoj djeci sa svrhom isticanja potrebe prikupljanja sustavnih podataka o ranoj pismenosti u hrvatskom jeziku/ pismu i oblikovanja materijala (upitnika, protokola, testa) za procjenu prema postojećim materijalima $i$ preporukama (Justice, Ivernizzi i Meier, 2002) i uz uvažavanje kulturoloških i jezičnih osobitosti, obilježja tiska (slikovnica, knjiga) i programa koji se provode u predškolskim ustanovama. Istraživanje je početak prikupljanja podataka iz najranije dobi (3-6 godina), kako bi se stvorile osnove za parametre očekivanih znanja pismenosti kod djece urednog razvoja.

\section{CILJ I PRETPOSTAVKE ISTRAŽIVANJA}

Cilj pilot ispitivanja je opisati znanja iz područja rane pismenosti trogodišnjaka i četverogodišnjaka, polaznika vrtića, prema materijalu sastavljenom od Upitnika za procjenu rane pismenosti, oblikovanom za potrebe istraživanja, koji sadrži procjenu koncepta tiska, izranjajućeg čitanja i pisanja i precrtavanja te od podtestova PredČip testa - Fonološka svjesnost i Poznavanje slova. Nastojat će se utvrditi postoji li razlika između trogodišnjaka i četverogodišnjaka u ukupnom postignuću na korištenom materijalu te mogu li se izdvojiti one skupine zadataka koje obje skupine djece najuspješnije rješavaju i one u kojima ispitana djeca postižu najniže rezultate. Kvalitativnom analizom opisat će se razine težina pojedinih skupina zadataka za trogodišnjake i četverogodišnjake. U skladu s ciljevima postavljene su dvije pretpostavke:

H1: Postojat će statistički značajna razlika u ukupnom rezultatu na materijalu za ispitivanje rane pismenosti, odnosno u razinama rane pismenosti, između trogodišnje i četverogodišnje djece.

H2: Postojat će razlika u težini zadataka za procjenu rane pismenosti između trogodišnje i četverogodišnje djece.

\section{METODE RADA}

\section{Uzorak ispitanika}

Prigodan uzorak ispitanika obuhvatio je 40-ero djece, 20 trogodišnjaka prosječne kronološke dobi 3.07 godina, 8 djevojčica i 12 dječaka te 20 četverogodišnjaka prosječne kronološke dobi 4.08 godina, 11 djevojčica i 9 dječaka. Svi ispitanici su 
polaznici Dječjeg vrtića Trešnjevka u Zagrebu. Na osnovi logopedskog probira kod ispitane djece nisu ustanovljena odstupanja u jezično govornom razvoju, niti su uvidom u dokumentaciju bila navedena bilo kakva druga odstupanja, a što su bili uvjeti za ispitivanje.

\section{Mjerni instrument - materijal za procjenu rane pismenosti}

Istraživanje je provedeno primjenom Upitnika za procjenu rane pismenosti oblikovanom prema već ranije korištenom materijalu i istraživanjima (Lenček, Ivšac Pavliša i Smiljanić, 2012; Lenček, Peretić i Ivšac Pavliša, 2011), nadopunjenog zadatcima fonološke svjesnosti i poznavanja slova iz predČip testa (Kuvač Kraljević, Lenček, 2012). Uz Upitnik za procjenu rane pismenosti, korištena je slikovnica „Medo Paddington u vrtu“ Michaela Bonda s prijevodom na hrvatski jezik iz 2011. godine, prilagođena za ispitivanje. Upitnik za procjenu rane pismenosti sadrži tri dijela. Prvi dio Upitnika (32 pitanja) odnosi se na koncept o tisku i namijenjen je (prema materijalima Whitehurst i Lonigan, 1998; Justice i Ezell, 2001; Pullen i Justice, 2003) ispitivanju znanja o čitanju, knjigama, poznavanju smjera čitanja, razlikovanju riječi, malih i velikih tiskanih slova te prepoznavanju interpunkcijskih znakova. Svako pitanje boduje se jednim bodom te je teorijski raspon rezultata na ovoj podcjelini, kasnije definiranoj skupnom varijablom Koncept o tisku (KOT), 0 do 32 boda. Drugi dio Upitnika odnosi se na zadatke izranjajuće pismenosti i ispituje globalno čitanje, izranjajuće pisanje, hvat, držanje olovke, pisanje slova i imenovanje napisanog slova te vještine početnog pisanja (poput npr. potpisivanja) i sadrži 7 pitanja. Kvantitativno su vrednovana 3 pitanja, a svako pitanje je nosilo 1 bod. Kvalitativno su vrednovana 4 pitanja. Teorijski raspon rezultata na ovoj podcjelini, odnosno na kasnije određenoj skupnoj varijabli Izranjajuća pismenost (IZR_ČIP), je 0 do 3 boda. Podcjelina grafomotoričke vještine ili precrtavanje treći je dio Upitnika i ispituje predvještine pisanja: djetetov je zadatak da precrta 4 zadane linije i 4 geometrijska lika - ukupno 8 zadanih predložaka. Postignuća na zadacima koji traže precrtavanje linija uključuju vrednovanje prema kriterijima (a) izvedenosti - prema dihotomnom kriteriju: izvedena linija $=1$ bod, neizvedena ili netočno izvedena linija $=0$ bodova $\mathrm{i}(\mathrm{b})$ prostornog smještaja - odgovarajuće prostorno smještena linija $=1$ bod, neodgovarajuće smještena $=0$ bodova. Ukupan mogući broj bodova je 8 . Na zadacima precrtavanja likova uz navedene kriterije (a) i (b) vrednuje se i treći kriterij (c) zatvorenost lika (kruga, kvadrata, trokuta, romba) također prema dihotomnom kriteriju - zatvoren lik nosi 1 bod, nezatvoren lik 0 bodova. Procjena precrtanosti likova ima raspon bodova od 0 do 12 . Na podcjelini precrtavanje, odnosno na kasnije definiranoj skupnoj varijabli Precrtavanje (PRECRT), dijete može ukupno ostvariti 0 do 20 bodova.

Fonološka svjesnost, definirana kao jedna od najprediktivnijih mjera početnog čitanja i pisanja, ispitana je zadacima iz PredČip testa (Kuvač Kraljević, Lenček, 2012) - raspoznavanje i proizvodnja rime, raščlamba rečenice na riječi, slogovno stapanje i raščlamba, fonemsko stapanje i raščlamba. Bodovanje je vršeno prema odrednicama testa tako da je ukupan broj bodova na ovoj podcjelini, kasnije određenoj kao varijabla Fonološka svjesnost (FS), od 0 do 49.

Zadatci poznavanja velikih i malih tiskanih slova ispituju se pomoću liste slova iz PredČiP testa i boduju se prema kriterijima testa: raspon bodova za velika tiskana slova je od 0 do 30, kao i za mala tiskana slova. Ukupan mogući broj bodova na poznavanju slova, odnosno kasnije određenoj skupnoj varijabli Poznavanje slova (POZ_SLOVA) je od 0 do 60 .

Ukupan mogući broj bodova na svim zadacima, koji je korišten za potrebe određenja varijable Ukupan rezultat (UK_REZ), je od 0 do 164.

Ispitivanje je provedeno individualno, a s obzirom na relativno velik broj zadataka, prema potrebi su uzimane stanke tijekom odgovaranja pojedine djece. Istraživanje je provedeno nakon dobivanja pristanka roditelja svakog pojedinog djeteta, a sve aktivnosti provedene su u skladu s etičkim načelima istraživanja koja se provode $\mathrm{s}$ djecom.

\section{Varijable istraživanja}

Definirane su prema korištenim zadatcima (Prikaz 1), a skupne varijable određene su u skladu s istraživanjima Whitehurst i Lonigan (1998). 
Prikaz 1. Varijable istraživanja

\begin{tabular}{|c|c|c|c|}
\hline & Naziv varijable & Kratica & Opis varijable \\
\hline 1 & spol & & Spol ispitanika \\
\hline 2 & dob & & Kronološka dob ispitanika \\
\hline 3 & koncept o čitanju & KOČ & Što možemo čitati \\
\hline 4 & prepoznavanje slikovnice & PREP_SLIK & Uporaba naziva slikovnica/knjiga \\
\hline 6 & čitanje & ČIT & Što radimo s knjigom \\
\hline 7 & prednja korica & PR_KOR & Prednja korica knjige \\
\hline 8 & stražnja korica & STR_KOR & Stražnja korica knjige \\
\hline 9 & gornji dio knjige & GDK & Gornji dio knjige \\
\hline 10 & donji dio knjige & DDK & Donji dio knjige \\
\hline & naslov & NASL & Naslov knjige \\
\hline & autor & AUTOR & Autor knjige \\
\hline & tekst & TEKST & Tekst - što je za čitanje \\
\hline & ilustracije & ILUSTR & Uloga ilustracije \\
\hline & početak čitanja & POČ_ČIT & Gdje počinjemo čitati \\
\hline & smjer čitanja & SMJER & Smjer u kojem čitamo \\
\hline & novi red & NOV_RED & Gdje nastavitičitati (kraj retka) \\
\hline & nova stranica & NOV_STR & Gdje početi čitati (kraj teksta na str.) \\
\hline & rečenica & REČ & Svjesnost rečenice \\
\hline & riječ & RIJEČ & Svjesnost riječi \\
\hline 21 & prva riječ & PRV_RIJEČ & Početna riječ na stranici \\
\hline & zadnja riječ & ZAD_RIJEČ & Zadnju riječ na stranici \\
\hline 23 & prvo slovo & PRV_SLOVO & Pokazivanje prvog slova u riječi \\
\hline & zadnje slovo & ZAD_SLOVO & Pokazivanje zadnjeg slova u riječi \\
\hline 25 & razlikovanje slova & RAZL_SLOV & Razlikovanje malih i velikih tiskanih slo \\
\hline 26 & 5 velika tiskana slova & VEL_SLOVA & Prepoznavanje velikih tiskanih slova \\
\hline 27 & 7 mala tiskana slova & MAL_SLOVA & Prepoznavanje malih tiskanih slova \\
\hline 28 & znakovi u priči & ZNAK & Interpunkcijski znakovi \\
\hline 29 & točka & TOČ & Prepoznavanje točke \\
\hline 30 & broj & BR & Prepoznavanje broja \\
\hline 31 & upitnik & UPIT & Prepoznavanje upitnika \\
\hline 32 & uskličnik & USKL & Prepoznavanje uskličnika \\
\hline 33 & zarez & ZAR & Prepoznavanje zareza \\
\hline 34 & navodnici & NAV & Prepoznavanje navodnika \\
\hline & numeriranje stranice & BR_STR & Uloga broja stranice \\
\hline 36 & 5 prepoznavanje riječi & GLOB_ČIT & Prepoznavanje obilježja napisane riječi \\
\hline 37 & pisanje slova & PIS_SLOVO & Pisanje jednog slova po izboru \\
\hline 38 & 3 imenovanje napisanog slova & IM_SLOVO & Znanje imena napisanog slova \\
\hline 39 & prostorno smještanje & PROSTOR & Prostorno smještanje linija i oblika \\
\hline 40 & izvedenost & IZVED & Izvedenost linija i oblika \\
\hline 41 & zatvorenost & ZATVOR & Zatvorenost oblika \\
\hline 42 & raspoznavanje rime & RAS_RIMA & Raspoznavanje rime \\
\hline 43 & proizvodnja rime & PRO_RIMA & Proizvodnja rime \\
\hline 44 & 4 raščlamba rečenice na riječi & RAŠČ_REČ & Raščlamba rečenica na riječi \\
\hline 45 & slogovna raščlamba & SLOG_RAŠČ & Slogovna raščlamba \\
\hline 46 & slogovno stapanje & SLOG_STAP & Slogovno stapanje \\
\hline 47 & 7 fonemska raščlamba & FON_RAŠČ & Fonemska raščlamba \\
\hline 48 & fonemsko stapanje & FON_STAP & Fonemsko stapanje \\
\hline 49 & broj velikih tiskanih slova & VTS & Prepoznata velika tiskana slova \\
\hline 50 & broj malih tiskanih slova & MTS & Prepoznata mala tiskana slova \\
\hline 51 & ukupni rezultat & UK_REZ & Ukupni rezultat na svim zadacima \\
\hline
\end{tabular}

Skupna varijabla

$\begin{array}{ll} & \text { A: 3-godišnjaci } \\ \text { koncept tiska } & \text { KOT } \\ \text { koncept tiska } & \text { KOT } \\ \text { koncept tiska } & \text { KOT } \\ \text { koncept tiska } & \text { KOT } \\ \text { koncept tiska } & \text { KOT } \\ \text { koncept tiska } & \text { KOT } \\ \text { koncept tiska } & \text { KOT } \\ \text { koncept tiska } & \text { KOT } \\ \text { koncept tiska } & \text { KOT } \\ \text { koncept tiska } & \text { KOT } \\ \text { koncept tiska } & \text { KOT } \\ \text { koncept tiska } & \text { KOT } \\ \text { koncept tiska } & \text { KOT } \\ \text { koncept tiska } & \text { KOT } \\ \text { koncept tiska } & \text { KOT } \\ \text { koncept tiska } & \text { KOT } \\ \text { koncept tiska } & \text { KOT } \\ \text { koncept tiska } & \text { KOT } \\ \text { koncept tiska } & \text { KOT } \\ \text { koncept tiska } & \text { KOT } \\ \text { koncept tiska } & \text { KOT } \\ \text { kOncept tiska } & \text { KOT }\end{array}$




\section{REZULTATI I RASPRAVA}

Izračunati su osnovni statistici za navedenih 5 skupnih varijabli i to za skupinu trogodišnjaka (A skupina) i za skupinu četverogodišnjaka (B skupina) (Tablica 1).

Trogodišnjaci postižu manji prosječan broj bodova od četverogodišnjaka na svim zadatcima Upitnika za procjenu rane pismenosti i na svim definiranim skupnim varijablama. Četverogodišnjaci su uspješniji u svim područjima tj. u ukupnom postignuću (postižu prosječno 66,30 boda od mogućih 164 na varijabli Ukupni rezultat UK_REZ) i na svakoj od skupnih varijabli. Obje skupine pokazuju relativno velika raspršenja rezultata na svim varijablama, osim na varijablama izranjajućeg čitanja i pisanja (IZR_ČIP) jer je mogući raspon rezultata $0-2$. Značajna raspršenja rezultata govore o neujednačenim postignućima, odnosno značajnim individualnim razlikama ispitane djece. Rezultati su usklađeni s razvojnim i očekivanjima prema razini i dužini odgojno - obrazovne uključenosti.

Kako bi se, u skladu s postavljenim ciljem i pretpostavkama istraživanja, mogle ispitati razlike između ispitanika, utvrđena je normalnost distribucije na ukupnom postignuću (varijabla UK_REZ) za svaku ispitanu skupinu djece (A skupina- trogodišnjaci i B skupina - četverogodišnjaci), za što je korišten Shapiro - Wilk test (Tablica 2).
Tablica 2. Vrijednosti dobivene Shapiro - Wilk testom za testiranje normalnosti distribucije na varijabli Ukupni rezultat (UK_REZ) za trogodišnjake (A skupina) $i$ četverogodišnjake (B skupina)

\begin{tabular}{|l|c|c|c|}
\hline $\begin{array}{l}\text { SKUPINA } \\
\text { ISPTANIKA }\end{array}$ & N & $\begin{array}{c}\text { Shapiro - } \\
\text { Wilk }\end{array}$ & P \\
\hline A & 20 & 0,755 & 0,000 \\
\hline B & 20 & 0,938 & 0,216 \\
\hline
\end{tabular}

Distribucija rezultata na varijabli Ukupni rezultat (UK_REZ) normalna je za četverogodišnjake, ali nije za trogodišnjake. Za utvrđivanje razlika u postignućima ispitane djece korišten je Mann - Whitney U test. Na varijabli Ukupni rezultat (UK_REZ) dobivene su statistički značajne razlike između trogodišnjaka i četverogodišnjaka i to na razini .01 (Tablica 3).

Tablica 3. Razlike u postignućima na varijabli Ukupan rezultat i skupnim varijablama Koncept o tisku (KOT), Izranjajuće čitanje i pisanje (IZR_ČIP), Precrtavanje (PRECRT), Fonološka svjesnost (FS), Poznavanje slova (POZ_SLOVA) između A skupine (trogodišnjaci)i B skupine (četverogodišnjaci); rezultati Mann - Whitney U testa

\begin{tabular}{|l|c|c|c|}
\hline VARIJABLA & Mann-Whitney U test & Z & P \\
\hline UK_REZ & 87,50 & $-3,045$ & 0,002 \\
\hline KOT & 92,00 & $-2,936$ & 0,003 \\
\hline IZR_ČIP & 137,00 & $-1,847$ & 0,065 \\
\hline PRECRT & 38,00 & $-4,398$ & 0,000 \\
\hline FS & 90,50 & $-2,968$ & 0,003 \\
\hline POZ_SLOVA & 108,00 & $-2,558$ & 0,011 \\
\hline
\end{tabular}

Tablica1. Deskriptivna statistika za varijable Ukupni rezultat (UK_REZ) i skupne varijable Koncept o tisku (KOT), Izranjajuće čitanje i pisanje (IZR_ČIP), Precrtavanje (PRECRT), Fonološka svjesnost (FS), Poznavanje slova (POZ_SLOVA) na materijalu za procjenu rane pismenosti za trogodišnjake (A skupina) i četverogodišnjake (B skupina)

\begin{tabular}{|l|c|c|c|c|c|c|c|}
\hline VARIJABLA & $\begin{array}{c}\text { SKUPINA } \\
\text { ISPITANIKA }\end{array}$ & N & MIN & MAX & M & SD & TR \\
\hline UK_REZ & $\mathrm{A}$ & 20 & 19 & 107 & 44,70 & 23,4253 & $0-164$ \\
\hline UK_REZ & $\mathrm{B}$ & 20 & 35 & 107 & 66,30 & 21,364 & $0-164$ \\
\hline KOT & $\mathrm{A}$ & 20 & 1 & 18 & 8,85 & 3,924 & $0-32$ \\
\hline KOT & $\mathrm{B}$ & 20 & 3 & 19 & 12,90 & 4,204 & $0-32$ \\
\hline IZR_ČIP & $\mathrm{A}$ & 20 & 0 & 2 & 0,60 & 0,883 & $0-3$ \\
\hline IZR_ČIP & $\mathrm{B}$ & 20 & 0 & 2 & 1,10 & 0,852 & $0-3$ \\
\hline PRECRT & $\mathrm{A}$ & 20 & 2 & 14 & 6,95 & 3,284 & $0-20$ \\
\hline PRECRT & $\mathrm{B}$ & 20 & 8 & 19 & 13,05 & 3,252 & $0-20$ \\
\hline FS & $\mathrm{A}$ & 20 & 13 & 35 & 20,40 & 4,999 & $0-49$ \\
\hline FS & $\mathrm{B}$ & 20 & 17 & 40 & 26,40 & 6,863 & $0-49$ \\
\hline POZ_SLOVA & $\mathrm{A}$ & 20 & 0 & 59 & 7,70 & 17,336 & $0-60$ \\
\hline POZ_SLOVA & $\mathrm{B}$ & 20 & 0 & 54 & 12,30 & 15,235 & $0-60$ \\
\hline
\end{tabular}


Dobivene su razlike očekivane zbog podataka da djeca u dobi između treće i četvrte godine napreduju u razvoju svih znanja i vještina koje pridonose ukupnom rezultatu na primijenjenom materijalu. Abou - Elsaad, Ali i El-Hamid (2015) su, prema rezultatima svog istraživanja, zaključili da kronološka dob ima važan utjecaj na razvoj fonološke svjesnosti i kasniju vještinu čitanja riječi, a Share i Gur (1999) su pokazali da mjere imenovanja slova, čitanja riječi, koncepta o tisku i fonološke svjesnosti predstavljaju pokazatelje razvojnih razlika u ranoj pismenosti. I u istraživanju koje su proveli Puranik i Lonigan (2011) trogodišnjaci postižu značajno niže rezultate od četverogodišnjaka i petogodišnjaka na varijablama pisanja slova, potpisivanja i glasovne raščlambe te zaključuju da djeca u navedenim godinama značajno napreduju u predvještinama pisanja odnosno rukopisnoj izvedbi zadanog. Daljnji nalazi dobiveni u našem istraživanju u skladu su s navedenim stranim istraživanjima: statistički značajne razlike između skupina ispitanika dobivene su na skupnim varijablama Koncept o tisku (KOT), Precrtavanje (PRECRT), Fonološka svjesnost (FS) i Poznavanje slova (POZ_SLOVA). Nema statistički značajne razlike na varijabli Izranjajuće čitanje (IZR_ČIP).

Usporedbom podataka koji sadrže postotke točnih odgovora na pojedinim varijablama, odnosno skupnim varijablama, uočena su neka obilježja rane pismenosti ispitanih trogodišnjaka i četverogodišnjaka koja pridonose objašnjenju navedenih razlika (Prikazi 2-12; Tablica 4 i 5) :

\section{KONCEPT O TISKU}

Ispitana djeca već u dobi od tri godine znaju da slikovnice i knjige čitamo, uspješna su u prepoznavanju smjera čitanja s lijeva na desno, uočavaju da postoje velika i mala tiskana slova i da se ona razlikuju te znaju gdje je naslov knjige/slikovnice. Uspješnost kojom pokazuju ova znanja (70 do 95\%) gotovo je podjednaka razini na kojoj to čine četverogodišnjaci (75 do 95\%) i stoga bi se moglo zaključiti da su ova znanja usvojena kod obje ispitane skupine (vidljivo u Prikazu 1 i 2). Dobiveni rezultati mogu se usporediti s rezultatima upitnika PWPA kojega su oblikovale Justice i Ezell (2001) koji se također oslanja na slikovnicu, a kojim se ispituje svjesnost o riječima i tisku kod četverogo- dišnjaka urednog razvoja. Na PWPA testu većina četverogodišnjaka (80\%) je razlikovala riječi napisane velikim i malim tiskanim slovima, prepoznavali su obilježja naslovnice, naslova knjige i smjera čitanja. Ovi rezultati pokazuju da su djeca ciljano bila poučavana o sadržajima slikovnica (formalno učenje).

Statistički značajnim razlikama između ispitanika na skupnoj varijabli Koncept tiska (KOT), a prema utvrđenim postocima točnih odgovora na pojedinim varijablama koje čine ovu skupnu varijablu (Prikaz 1 i 2), pridonose zadatci koji uključuju znanja o: funkciji broja stranice, gdje nastavljamo čitati tekst (okretanje stranice), o mjestu gdje piše autor slikovnice. Na ovim zadatcima četverogodišnjaci su uspješniji od trogodišnjaka. Prema postotcima točnih odgovora na zadatku prepoznavanja prvog i zadnjeg slova na stranici, naši trogodišnjaci tek ulaze u fazu osvještavanja slova kao entiteta koji gradi riječi: njih 35\% uspješno prepoznaje slovo na početku i kraju riječi. Među četverogodišnjacima su ova znanja bitno prisutnija: $60 \%$ ih uspješno pokazuje prvo i zadnje slovo u odabranoj riječi. Djeca ispitana u našem istraživanju nemaju usvojena znanja o riječi: neuspješna su u pokazivanju prve riječi na stranici (samo 10\% trogodišnjaka i $10 \%$ četverogodišnjaka to može učiniti) kao i zadnje riječi na stranici (niti jedan trogodišnjak ne može pokazati zadnju riječ na stranici, a među četverogodišnjacima je samo $5 \%$ one djece koja je mogu pokazati). Na PWPA testu manje od $20 \%$ ispitanika uspješno je riješilo zadatak u kojem se traži pokazivanje prve riječi na stranici, dok zadnju riječ na stranici nije pokazao niti jedan četverogodišnjak (Justice i Ezell, 2001). Iz ovih usporedbi može se zaključiti da djeca u našem istraživanju, baš kao i ona koje su ispitale Justice i Ezell (2001), još uvijek nemaju usvojen koncept riječi tj. svjesnost o riječima. Svjesnost o riječima odnosi se na djetetovu sposobnost prepoznavanja riječi kao elemenata tiska i govora. Brown (2014) navodi da se svjesnost o riječima u tisku razvija na način da dijete najprije razumije da je svaka riječ u tekstu odvojena, odnosno da su riječi u rečenici odvojene prazninom. Direktno poučavanje ovim znanjima daje mnogo bolje rezultate na kasnijim mjerama školske pismenosti nego indirektno poučavanje, kako navodi Johnson (2015). Ova autorica navodi 


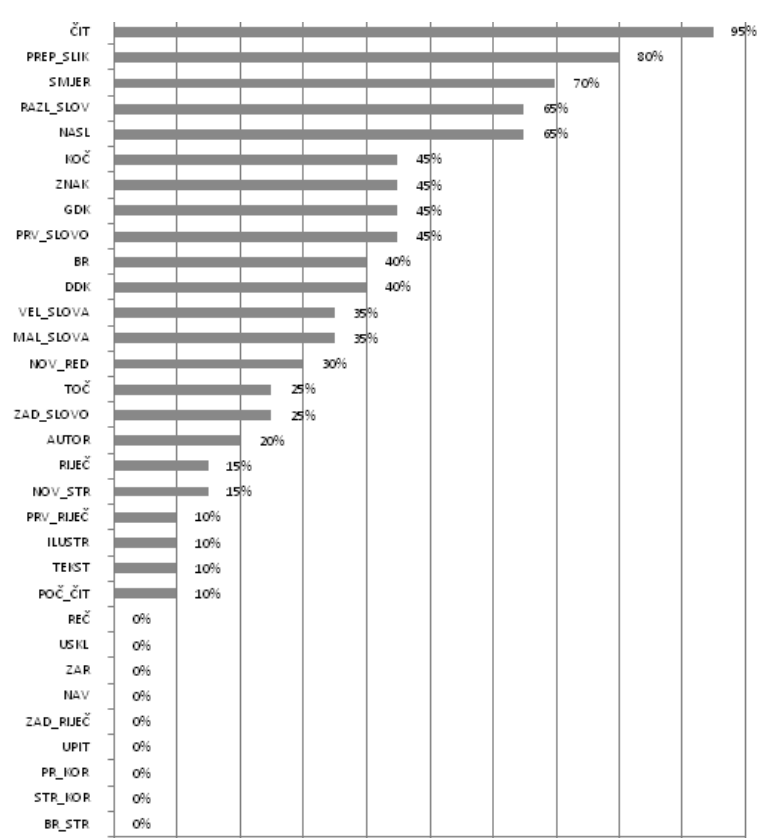

$0 \% \quad 10 \% \quad 20 \% \quad 30 \% \quad 40 \% \quad 50 \% \quad 60 \% \quad 70 \% \quad 80 \% \quad 90 \% \quad 100 \%$

Prikaz 2. Postotak uspješnosti rješavanja pojedinih zadataka na skupnoj varijabli Koncept tiska kod skupine A - kod trogodišnjaka

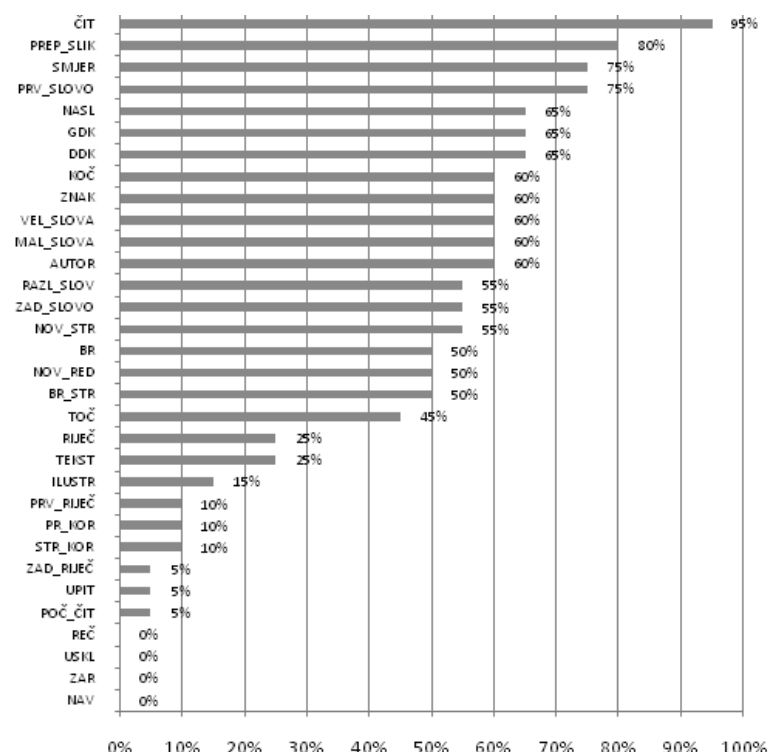

Prikaz 3. Postotak uspješnosti rješavanja pojedinih zadataka na skupnoj varijabli Koncept tiska kod skupine $B$ - kod četverogodišnjaka

i značajno bolje rezultate djece na konceptu tiska kada su neposredno poučavana npr. interpunkcijskim znakovima (zarez, navodnici). U našem su istraživanju zadatci koji ispituju prepoznavanje interpunkcijskih znakova (točke, upitnika...) bili potpuno nerazumljivi i nerješivi za trogodišnjake, a načelno i za četverogodišnjake, a što je ispod razine znanja prema razvojnim standardima za npr. američku djecu. Već spomenuto neposredno poučavanje moglo bi poboljšati svjesnost o tisku kod djece $u$ hrvatskom predškolskom sustavu.

Ispitani trogodišnjaci i četverogodišnjaci u našem istraživanju nemaju predodžbu o tome što je rečenica, ne prepoznaju koncept rečenice, baš kao ni koncept riječi, što govori o potrebi poučavanja i u ovom segmentu svjesnosti o tisku, odnosno rane pismenosti. Moguće je da nepoznavanje dijela činjenica o konceptu tiska proizlazi iz nedostatnosti tzv. zajedničkog čitanja (shared reading) koje se može ostvariti u kućnom okruženju (roditelj - dijete) ili u obrazovnom okruženju (odgajatelj - djeca). Zajedničko čitanje jedna je od snažno promicanih aktivnosti za poticanje razvoja rane pismenosti (Senechal i sur., 2008; Piasta i sur., 2012) koja se kod nas još uvijek nedostatno istražuje i zagovara, a pruža niz prilika za razmatranje uloge teksta, znanja o vezi slovo-glas te niza drugih spoznaja koje određuju ranu pismenost. Brown (2014) navodi da kroz zajedničko čitanje članovi obitelji postavljaju model za čitanje i zapravo podučavaju djecu ranoj pismenosti.

\section{IZRANJAJUĆE ČITANJE I PISANJE}

Izranjajuće čitanje i pisanje je kao skupna varijabla (IZR_ČIP) određena prema shvaćanjima Whitehurst i Lonigan (1998) i kvantitativno je vrednovana kroz tri zadatka. Nema statistički značajnih razlika između trogodišnjaka u odnosu na četverogodišnjake na ovoj skupnoj varijabli. U kvaliteti odgovora ipak su vidljive neke razlike između trogodišnjaka i četverogodišnjaka. Prema postotcima točnih odgovora (Tablica 4) moguće je izdvojiti nekoliko značajki izranjajućeg čitanja i pisanja: (1) Trogodišnjaci i četverogodišnjaci nemaju znanja koja bi osigurala prepoznavanje obilježja riječi u hrvatskom jeziku i „hrvatskoj latinici“" $(0 \%$ prepoznatih riječi; uključuje znanja poput neponavljanja samoglasnika u smislenim riječima, prepoznavanja „slika“ slova koja ne pripadaju latiničnom pismu/simboli poput npr. Д). Djeca se nedostatno oslanjanju na vizualno prepoznavanje obilježja i nisu poučena znanjima koja to prepoznavanje riječi osiguravaju. (2) Pisanje slova (Tablica 4) značajno se poboljšava s dobi $(70 \%$ 
točnih odgovora četverogodišnjaka i 35\% kod trogodišnjaka), što nije samo razvojno uvjetovano, već je posljedica formalne ili neformalne poduke (Puranik i Lonigan, 2011; i Puranik i sur., 2014).

Purank i Lonigan (2011) u rezultatima istraživanja pokazuju da djeca najčešće pišu slovo $O$, a zatim A i T. Navedena slova najlakša su u smislu grafomotoričke izvedbe, a slovo A je među najzastupljenijima u riječima i najčešći je primjer slova. Trogodišnjaci u našem istraživanju najčešće su pisali O i A, a četverogodišnjaci T i A. Premda je razlika na varijabli PIS_SLOVO značajna, ona ne pridonosi dostatno za statističko razlikovanje ispitanika dviju skupina na skupnoj varijabli Izranjajuće čitanje i pisanje. (3) Imenovanje napisanog slova teže je od samog pisanja slova - tek dio djece koja su napisala slovo zna ga imenovati, ali razlike tro- i četvero-godišnjaka nisu značajne. Pisanje slova u ranoj dobi (Tablica 4) temelji se kod djece u našem istraživanju pretežno na vizualnoj percepciji, diskriminaciji i grafomotorici, i uglavnom nema oslonac u jezičnom znanju na razini veze slovo-glas, osim možda kod jezično „,naprednih“ pojedinaca. U okruženjima s programima poticanja rane pismenosti koji naglašavaju uspostavu veze slovo-glas i poznavanje slova (kao što je to npr. Head Start program; SAD) u dobi od četiri godine očekuje se poznavanje najmanje desetak slova i uspostavljena veza govor/glas - pismo/ slovo. U tzv. transparentnim jezicima, rano imenovanje slova može značajno pridonijeti početnom čitanju i pisanju (Furnes i Samuelsson, 2010), pri čemu je značajna uloga programa koji potiču usvajanje slova i alfabetskog principa.

Tablica 4. Postotak uspješno riješenih zadataka na skupnoj varijabli Izranjajuće čitanje i pisanje IZR_ĊIP) kod skupine A (trogodišnjaci) $i$ skupine B (četverogodišnjaci)

\begin{tabular}{|l|c|c|c|}
\hline $\begin{array}{l}\text { SKUPINA } \\
\text { ISPTANIKA }\end{array}$ & GLOB_ČIT & PIS_SLOVO & IM_SLOVO \\
\hline A & - & $35 \%$ & $25 \%$ \\
\hline B & - & $70 \%$ & $40 \%$ \\
\hline
\end{tabular}

Kvalitativna analiza obuhvatila je i mjere koje se odnose na hvat olovke, pisanje i potpis, a rezultati tog dijela istraživanja bit će obrađeni kao sastavni dio posebnog rada.

\section{PRECRTAVANJE}

Zadaci precrtavanja uvršteni su $u$ ispitivanje zbog činjenice da su dječje vještine crtanja i precrtavanja posebno važan dio predvještina pisanja. Ispitanicima su ponuđene četiri linije (okomita, vodoravna, kosa uzlazna i silazna) te četiri oblika (krug, četverokut, trokut, romb) za precrtavanje te se nije očekivalo da će sva djeca moći izvesti sve ponuđene zadatke. Na skupnoj varijabli Precrtavanje dobivene su statistički značajne razlike u uspješnosti između djece $u$ dobi od tri i četiri godine. Uspješniji su četverogodišnjaci, pri čemu je iz rezultata istraživanja vidljivo (Prikaz 4 i 5) sljedeće: (1) Obje skupine ispitane djece najuspješnije su u precrtavanju okomite linije i kruga, što potvrđuje dobru ovladanost grafomotoričkom izvedbom jednostavnih formi i u skladu je s razvojnim parametrima (Gerde i sur., 1992). (2) Očekivane razlike najvidljivije su u mogućnosti izvođenja kosih linija: četverogodišnjaci su značajno bolji. (3) Silazne kose linije ( ) jednostavnije su za izvedbu od uzlaznih kosih linija (/) za svu ispitanu djecu. (4) Trogodišnjaci u pravilu precrtavaju i zatvaraju samo krug, dok četverokut uspješno izvede i zatvori $25 \%$ trogodišnjaka, a trokut i romb nije moglo precrtati niti jedno trogodišnje dijete (što je u skladu s očekivanjima i razvojnim pokazateljima. (5) Između treće i četvrte godine, prema podatcima naših ispitanika, događa se značajan napredak u grafomotoričkoj izvedbi, što je značajno za kasnije pisanje (Clark, 2010). U dobi od četiri godine $95 \%$ ispitane djece u istraživanju uspješno precrtava četverokut, 50\% uspješno izvede trokut, a romb čak $25 \%$ djece. Ovakvi rezultati pridonose statistički značajnim razlikama ispitanika u dobi od tri i četiri godine.

Kako grafomotorika obuhvaća i primjereno planiranje i korištenje prostora, daljnji rezultati precrtavanja odnose se na vještine prostornog smještanja i nadopunjavaju prethodne podatke.

(6) Uspješnost prostornog smještanja u zadacima precrtavanja povećava se s porastom kronološke dobi, pri čemu nije moguće točno utvrditi udio okolinskih čimbenika. Naime, prema osam zadanih predložaka za precrtavanje, trogodišnjaci su u prosjeku prostorno uspješno smjestili 30\% zadanog, i u tom su prosjeku značajno lošiji od 


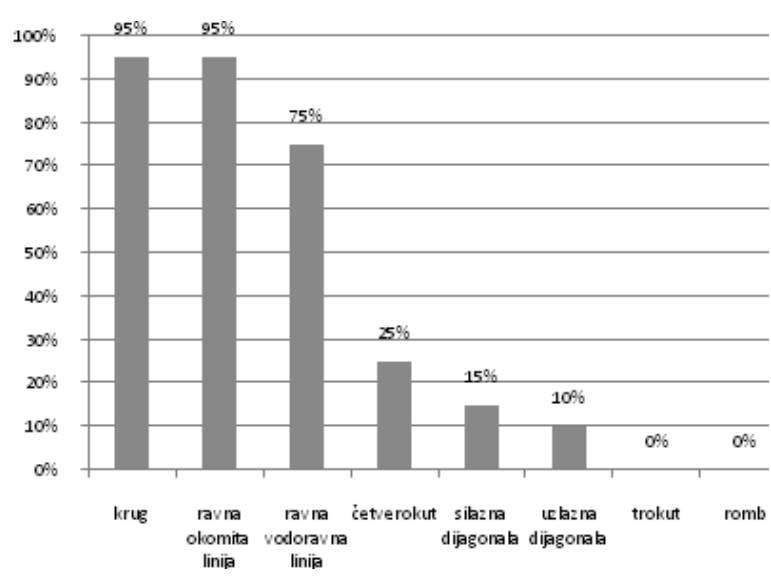

Prikaz 4. Postotak uspješne riješenosti za varijablu izvedenost (IZVED) kod trogodišnjaka

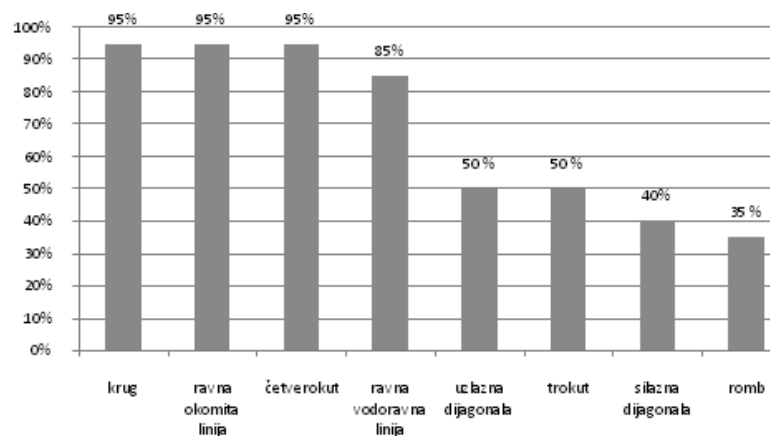

Prikaz 5. Postotak uspješne riješenosti za varijablu izvedenost (IZVED) kod četverogodišnjaka

četverogodišnjaka, koji prosječno točno smještaju $62,5 \%$ zadanog. Ovi rezultati govore u prilog razvojnoj uvjetovanosti vještina prostornog smještaja kakvu navode i Marr, Windsor i Cermak (2001). (6) Rezultati na varijabli PROSTOR kod trogodišnjaka u potpunosti prate razvojnu liniju usvajanja izvedbe pojedinih elemenata precrtavanja (linije, likovi). Četverogodišnjaci ne prate navedeni slijed i uspješnost prostornog smještanja nije uvjetovana jednostavnošću izvedbe zadanih linija i likova. Valja napomenuti da se za obje skupine ispitanika procjena prostornog smještaja nije temeljila na uspješnosti u izvedenosti linija i likova već je prostorni smještaj procijenjen i kod likova koji po izvedenosti nisu u potpunosti odgovarali zadanome. (7) Usporedbama rezultata precrtavanja ispitane djece rane vrtićke dobi i standarda i normi koji su dostupni za neke testove (poput Visal Motor Integration testa; Beery i Beery, 2006, prema Clark 2010) kao i miljokaza grafomotoričkog razvoja, vještine kojima su ovladali ispitani trogodišnjaci

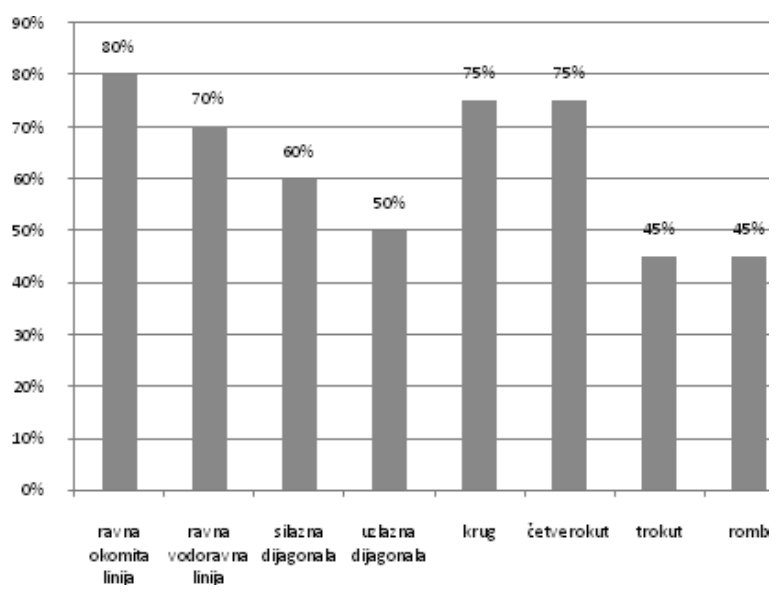

Prikaz 6. Uspješnost riješenosti za varijablu prostorno smještanje (PROSTOR) kod četverogodišnjaka

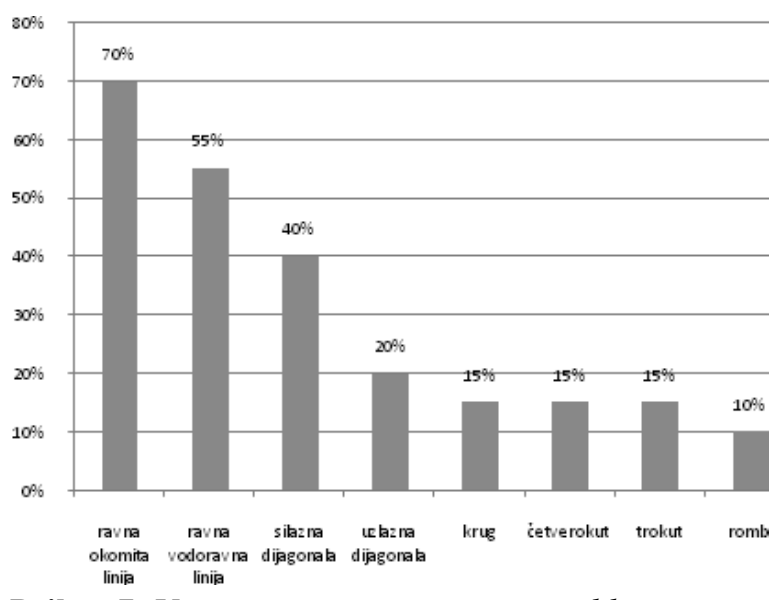

Prikaz 7. Uspješnost riješenosti za varijablu prostorno smještanje (PROSTOR) kod trogodišnjaka

i četverogodišnjaci u skladu su s očekivanjima za dob.

\section{FONOLOŠKA SVJESNOST}

Premda je fonološka svjesnost zasigurno najistraženiji aspekt rane pismenosti općenito, a istraživana je i kod nas (u odnosu na neznatan ili čak nikakav broj istraživačkih radova iz nekih drugih aspekata rane pismenosti, npr. Lenček, 1995; Lenček i Ivšac Pavliša 2011; Lenček i Kuvač Kraljević, 2012; Kolić Vehovec 2003), podaci ovog istraživanja uključuju primjenu materijala za utvrđivanje fonološke svjesnosti na djeci u dobi od tri $\mathrm{i}$ četiri godine, a o čemu ima izuzetno malo podataka. Korišten je podtest Fonološka svjesnost predČip testa (Kuvač Kraljević i Lenček, 2012), premda je ovaj cjeloviti test oblikovan za dob stariju od 5.11 
godina. Razlog primjene jest uključenost zadataka svjesnosti rime, sloga i prepoznavanja riječi u rečenici, a što bi, prema dobnim odrednicama, trogodišnjaci i četverogodišnjaci trebali uspješno rješavati (Ivšac Pavliša i Lenček, 2011). Rezultati pokazuju statistički značajne razlike na razini .01 na skupnoj varijabli Fonološka svjesnost (FS), pri čemu su, kao što je i očekivano, trogodišnjaci manje uspješni od četverogodišnjaka, što je u skladu s nizom istraživanja (Antony i Francis, 2005). Kvalitativna raščlamba rezultata na pojedinačnim varijablama uključenima u skupnu varijablu Fonološka svjesnost (FS) pokazuje kako su trogodišnjaci i četverogodišnjaci relativno dobro ovladali dijeljenjem rečenica na riječi, stapanjem i raščlambom slogova, prepoznavanjem i proizvodnjom rime, te da ima djece koja uspijevaju riješiti i zadatke fonemske svjesnosti - stapanja i raščlambe fonema.

U zadatku prepoznavanja i odjeljivanja riječi u rečenici (varijabla RAŠČC_REČ) postignuća ispitane djece začuđujuće su visoka s obzirom na činjenicu nepoznavanja riječi u pisanom obliku: trogodišnjaci su u prosjeku točno odjeljivali riječi u čak tri od sedam ponuđenih rečenica. Moats (2000, prema Kaderavek i Justice, 2004) navodi da se raščlamba rečenica na riječi očekuje upravo između ranog i kasnog predškolskog razdoblja. U odnosu na činjenicu neuspješnog prepoznavanja riječi u pisanom tekstu, ovaj podatak o prepoznavanju riječi u govorenim rečenicama, ali ne i u pisanom obliku, potvrđuje pretpostavku o mogućim nedostatnostima poduke. Programima bi se trebalo približiti znanja o govornom jeziku i pisanom konceptu. Piasta i sur. (2012) upravo ističu da znanja o tisku mogu biti ključna odrednica uspjeha $\mathrm{u}$ formalnom podučavanju pismenosti, posebno $\mathrm{u}$ „lomljenju alfabetskog koda“ i zagovaraju neposredno podučavanje koncepta tiska.

Rezultati koje postižu trogodišnjaci i četverogodišnjaci na zadatcima fonološke svjesnosti pokazuju da već poznata razvojna uvjetovanost znanja o dijelovima manjima od riječi, odnosno o strukturi riječi, može biti korištena kao osnova ispitivačkog materijala: podtest Fonološka svjesnost iz PredČip testa moguće je primjenjivati na mlađoj djeci, ali uvažavajući činjenicu da su norme izrađene za stariju djecu i kao takve ne mogu biti primjenjivane.

\section{IMENOVANJE SLOVA}

Utvrđena je statistički značajna razlika (na razini .01) između ispitanih trogodišnjaka i četverogodišnjaka na skupnoj varijabli Poznavanje slova (POZ_SLOVA), koja sadrži dvije varijable: poznavanje velikih i poznavanje malih tiskanih slova (VTS i MTS). Nedvojbeno je da imenovanje slova predstavlja najznačajniji pojedinačni prediktor čitanja, kako u dosljednim tako i u manje dosljednim ili posve nedosljednim ortografijama (Gallagher, Frith i Snowling, 2000; Torpa i sur., 2006; Georgiou i sur., 2012). Uvidom u postignuća djece starosti tri i četiri godine (Tablica 5, Prikaz 9 i 10) vidljiva su neka obilježja usvajanja slova hrvatske latinice:

Tablica 5. Postotak uspješno riješenih zadataka na varijabli Prepoznavanje velikih tiskanih slova (VTS) $i$ varijabli Prepoznavanje malih tiskanih slova (MTS) kod (A) skupine (trogodišnjaci) i B skupine (četverogodišnjaci)

\begin{tabular}{|l|c|c|}
\hline SKUPINA ISPTANIKA & VTS & MTS \\
\hline A & $14,6 \%$ & $11,6 \%$ \\
\hline B & $27 \%$ & $14 \%$ \\
\hline
\end{tabular}

Velika tiskana slova bolje su usvojena nego mala tiskana slova, kao i u većini jezika i pisama, a što je rezultat poučavanja. Trogodišnjaci poznaju relativno mali broj slova (prosječno približno 5 slova), što je i očekivano s obzirom na dob. U ovom ranom razvojnom razdoblju dobivaju tek sporadične informacije o slovima. Imenovanje slova kod četverogodišnjaka dvostruko je uspješnije - oni imenuju u prosjeku 9 slova. U usporedbi s nekih drugim jezicima i pismima, posebno u zemljama koje naglašavaju važnost znanja slova (npr. floridski razvojni standardi / Florida Birth to Five Early Learning and Developmental Standards, 2011), prema kojima se očekuje da četverogodišnjaci znaju sva slova, naši ispitanici poznaju znatno manji broj slova od očekivanoga. Nova istraživanja Lyytinen i sur. (2015) tvrde da djetetov rezultat poznavanja slova u dobi od pet godina može gotovo u potpunosti točno predvidjeti hoće li dijete imati teškoće čitanja u školskoj dobi. Prema svim ovim podatcima značaj poduke slova postaje još važniji. Daljnjom raščlambom podataka dobiven je poredak usvojenosti za svako pojedino veliko tiskano slovo kod trogodišnjaka i četverogodišnjaka (Prikaz 9 i 10): 


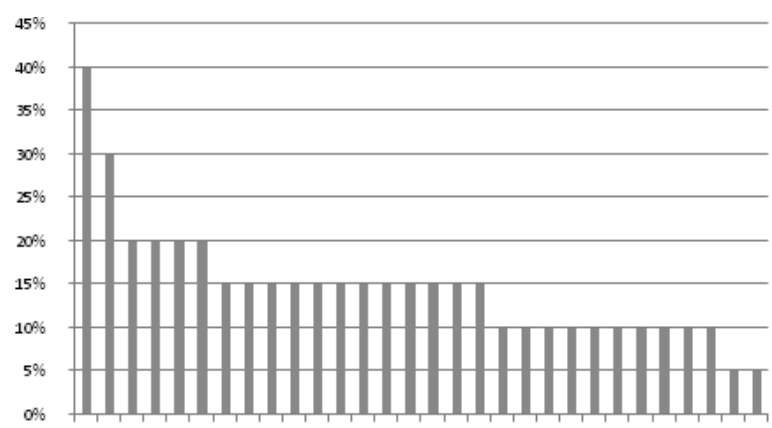

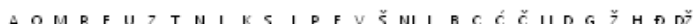

Prikaz 9. Uspješnost prepoznavanja pojedinih velikih tiskanih slova (VTS) kod trogodišnjaka

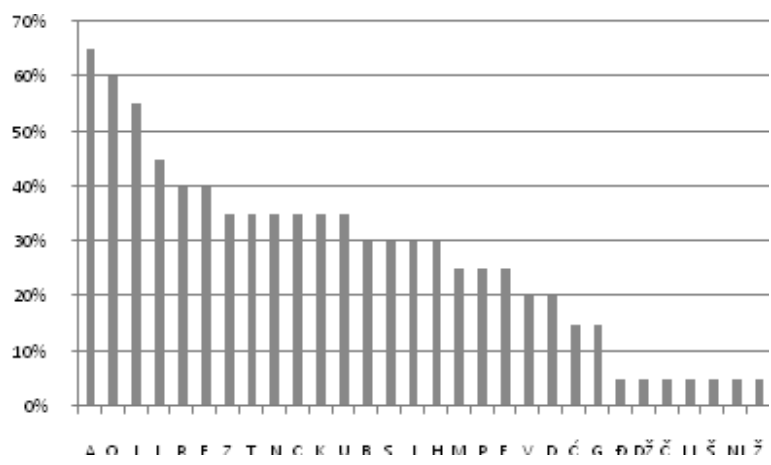

Prikaz 10. Postotak uspješnog imenovanja na varijabli Velika tiskana slova (VTS) kod B skupine (četverogodišnjaci)

Osim prva dva slova $(A, O)$, poredak ostalih slova je neujednačen s obzirom na postotak uspješnog imenovanja kod trogodišnjaka i četverogodišnjaka. $A$ je slovo koje sva ispitana djeca najlakše imenuju. Ono je i među najučestalijima u govoru i tekstu, a najčešće predstavlja ,primjer“ što je slovo prilikom objašnjavanja simboličke funkcije. Slovo $\mathrm{O}$ je, osim visoke učestalosti u govoru i tekstu, grafički među najjednostavnijima i usporediv je s poznatim likom/objektom - krugom. Za obje je skupine najmanja uspješnost imenovanja vezana uz slova s dijakritičkim znakovima, što je vidljivo i iz nekih ranijih istraživanja (Vancaš, 1999). Imenovanje slova kod ispitane djece pokazuje ovladavanje ovim znanjima prema kriterijima učestalosti pojavljivanja slova, grafičke jednostavnosti ili upečatljivosti i povezivanja s bliskom osobnim iskustvima i određenjima.

$\mathrm{S}$ ciljem utvrđivanja razlika u težini ispitanih zadataka izračunati su postotci uspješnosti na skupnim varijablama za A skupinu A (trogodišnjaci) i
B skupinu (četverogodišnjaci). Rezultati su vidljivi u Prikazima 11 i 12.

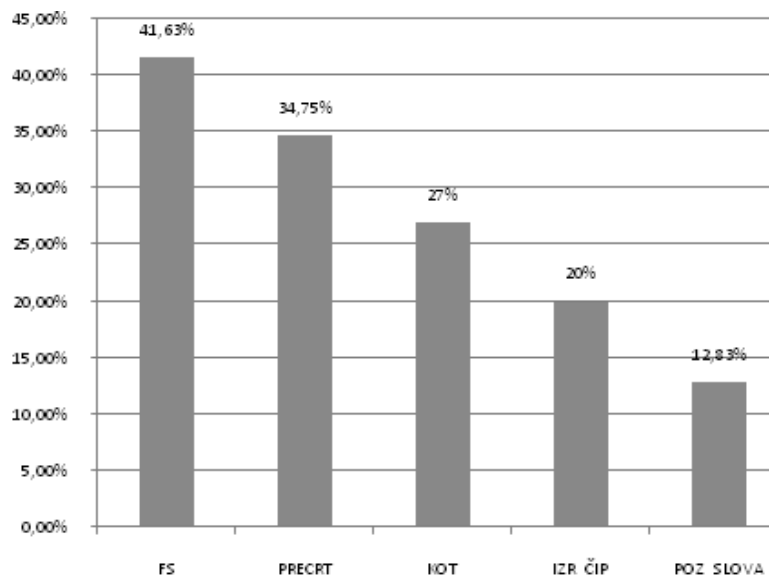

Prikaz 11. Postotak uspješno riješenih zadataka na skupnim varijablama kod A skupine (trogodišnjaci)

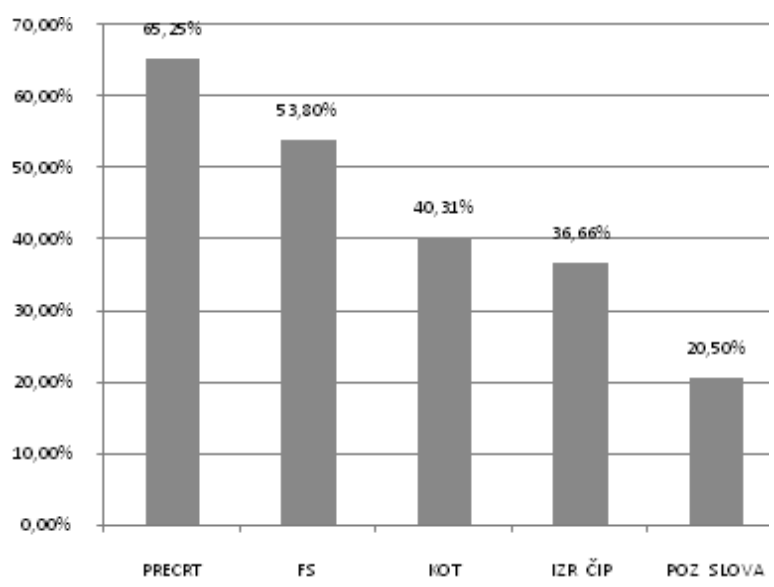

Prikaz 12. Postotak uspješno riješenih zadataka na skupnim varijablama kod B skupine (četverogodišnjaci)

Na svim skupnim varijablama trogodišnjaci su manje uspješni od četverogodišnjaka, odnosno s porastom dobi raste točnost rješavanja na svim postavljenim zadacima.

Trogodišnjaci najuspješnije rješavaju zadatke fonološke svjesnosti, a zatim zadatke precrtavanja. Programi predškolskog odgoja očito značajno potiču razvoj fonološke svjesnosti u ranom razdoblju i stoga i trogodišnjaci i četverogodišnjaci uspješno rješavaju zadatke koji uključuju slogove, rimu i izdvajanje riječi u rečenicama. Kod četverogodišnjaka je poredak uspješnosti na ove dvije skupne varijable - Fonološkoj svjesnosti (FS) i Precrtavanju (PRECRT) obrnut, što govori u prilog 
mogućem značajnijem razvoju i usvajanju grafomotoričkih vještina upravo između treće i četvrte godine. Maturacijski uvjeti u domeni motorike i stvaranje preduvjeta u vidu motoričke zrelosti za izvedbu i razvoj perceptivnih sposobnosti (Marr, Windsor i Cermak, 2001) omogućavaju dobru izvedbu kod zadataka precrtavanja. Osim dobne uvjetovanosti, grafomotoričke se vještine snažno potiču kao aktivnosti u našim vrtićima.

Podaci o konceptu o tisku i izranjajućem čitanju i pisanju pokazuju razine koje su ispod očekivanih postignuća u odnosu na podatke stranih istraživanja (Justice i Ezell, 2001; Piasta i Wagner, 2010), odnosno pokazuju da su neki od zadataka nerješivi, a time i preteški za naše tro- $i$ četverogodišnjake. Niz ispitivanja dokazuje da su upravo koncept tiska i vještine koje se ubrajaju u izranjajuće čitanje i pisanje ključni za kasniju pismenost te se mogu usvojiti vrlo rano. Djeca ispitana u našem istraživanju čine se kao ,na pola puta" $u$ odnosu na postignuća opisana u istraživanjima američkih, europskih i drugih autora (Justice, Ivernizzi i Meier, 2002; Li i Rao, 2005; Torppa i sur., 2010; Wildova i Kropačkova, 2015). Utjecaj dobi vidljiv je i u ove dvije skupne varijable (KOT i IZR_ČIP): s porastom dobi raste i uspješnost u rješavanju svih zadataka unutar ovih skupnih varijabli.

Imenovanje/poznavanje slova (skupna varijabla POZ_SLOVA) bi, prema dosadašnjim našim istraživanjima (Lenček, Kuvač Kraljević i Matešić, 2012) i programima predškolskog odgoja, odgovaralo ranijim podacima i očekivanim razinama vezanima uz trogodišnjake i četverogodišnjake. Međutim, novije spoznaje ističu potrebu ranijeg i boljeg poznavanja slova u smislu doprinosa ranoj pismenosti, posebno kod četverogodišnjaka.

Temeljem rezultata i rasprave prihvaćaju se postavljene pretpostavke istraživanja: postoji statistički značajna razlika u ukupnom rezultatu na materijalu za ispitivanje rane pismenosti, između trogodišnje i četverogodišnje djece polaznika vrtića. Postoji i razlika u težini zadataka za procjenu rane pismenosti između trogodišnje i četverogodišnje djece polaznika vrtića.

\section{ZAKLJUČAK}

Rano razvojno razdoblje posebno je važno za učenja koja se ostvaruju tijekom cijelog života.
Rana pismenost, kao temelj usvajanja i kasnijeg razvoja pismenosti, naročito snažno utječe na školsko razdoblje i akademski uspjeh ili neuspjeh i određena je pokazateljima poput svjesnosti i motivacije za tisak, osnovnih rukopisnih znanja, poznavanja slova, fonološke svjesnosti i drugih mjera jezičnog razvoja (kao što su mjere narativnih sposobnosti, rječničkog znanja i druge). Utvrđivanjem razina navedenih znanja, postojanjem mjernih instrumenata $\mathrm{i} / \mathrm{ili}$ protokola $\mathrm{s}$ jasno definiranim sastavnicama praćenja, potom normama i standardima urednog razvoja, ostvaruje se briga za pismenost kao osobnu i društvenu vrijednost. Potencijali i odgovornosti koju struke, poput logopedske, imaju u domeni istraživačkog i stručnog rada u procjeni rane pismenosti, potrebno je koristiti kao aktivni pokretač promjena i jačanja svijesti o važnosti rane dobi za akademske, a onda i životne ishode. Otkrivanje rizika za nastanak teškoća u domeni pismenosti, odnosno prepoznavanje one djece koja neće moći uspješno ovladati čitanjem i pisanjem prije nego se ove vještine formalno započnu podučavati, otvara mogućnosti ,nadokna$\mathrm{de}^{\text {" }} \mathrm{kroz}$ intervencijske postupke ili usmjeravanja u drugačije načine podučavanja sa svrhom dobrog obrazovnog napretka i uspješnog učenja.

Rezultati ovog pilot ispitivanja pokazali su da je moguće oblikovati formalni (testovni) ili manje formalni materijal (protokol) koji će, kao osnova procjene, dati smjernice za rad s grupama djece određene dobi ili, ukoliko postoji potreba, za rad s pojedincima. Za izradu materijala potrebno je uvažiti ograničenja koja ima ovo ispitivanje i osigurati opsežnija istraživanja na većem uzorku ispitanika, promjene koje bi uključile uvrštavanje pitanja o svrsi čitanja, kao i pitanja usmjerena na dobivanje podataka o obilježjima kućnog okruženja vezanog uz pismenost, posebno o aktivnostima zajedničkog čitanja. Materijal bi trebala pratiti slikovnica isključivo namijenjena ispitivanju, a segmente fonološke svjesnosti, poznavanja slova, narativnih sposobnosti kao i drugih jezičnih znanja moglo bi se definirati na razini probira. Postupci temeljeni na materijalu trebaju služiti procjeni (ne testiranju) $\mathrm{u}$ skladu s definicijom danom u Encyclopedia of Educational Evaluation (prema Anderson i sur., 1975), što znači da bi uključivali proces prikupljanja podataka na takav način da su oni razumljivi i 
upotrebljivi za donošenje konačnih prosudbi prema višestrukim pokazateljima, izvorima i podatcima.

Podaci pilot ispitivanja pokazali su jasnu uzlaznu razvojnu liniju ostvarene rane pismenosti pri čemu, zbog nepostojanja jedinstvenog programa predškolskog odgoja, nije moguće zaključivati o vrijednosti poduke i samih programa: jedinstveni program rane pismenosti na nacionalnoj razini osigurao bi bolji uvid u one vještine i znanja koje je potrebno dodatno poticati ili kod kojih je potrebna intervencija. Za njegovo oblikovanje važno je uvažavati rezultate pismenosti u kasnijoj dobi jer manjkavosti koje se tada vide i bilježe, mogu biti uspješno uklonjene upravo ranom intervencijom (Greenwood i sur., 2016).
Posebnu pozornost $\mathrm{u}$ ispitivanju rane pismenosti trebalo bi usmjeriti na kvalitetne i svrhovite materijale za procjenu vještina rukopisne izvedbe jer su problemi pisanja (ne samo izvedbe, već sadržaja), prema nizu autora, najčešći razlog pružanja nekih oblika pomoći i terapijskih postupaka (Schneck i Amundson, 2010). Osim toga, 60\% vremena unutar školskog dana sadrži zadatke koji traže izvođenje fino-motoričkih radnji (McHall i Cermak, 1992, prema Lust i Donica, 2011), od kojih je najučestaliji zadatak pisanja.

Procjena rane pismenosti treba se odvijati uz uvažavanje obilježja sazrijevanja i udjela poučavanja u svakom zasebnom aspektu te uz uvažavanje osobitosti jezika i pisma. 


\section{LITERATURA}

Abou-Elsaad, T., Ali, R., El-Hamid, H. A. (2016): Assessment of Arabic phonological awareness and its relation to word reading ability. Logopedics Phoniatrics Vocology, 41, 4, 174-180.

Anderson, S. C. i sur. (1991): Encyclopedia of Educational Evaluation. San Francisco: Jossey-Bass.

Anthony, J.L., Francis, D. (2005): Development of phonological awareness. Current Directions in Psychological Science, 14, 5, 255-259.

Brown, S. C. (2014:. Language and Literacy Development in the Early Years: Foundational Skills that Support Emergent Readers. The Language and Literacy Spectrum, 24, 35 - 48.

Carroll, J. M., Snowling, M. J., Hulme, Ch., Stevenson, J. (2003): The Development of Phonological Awareness in Preschool Children. Developmental Psychology,. 39, 5, 913-923.

Caspe, M. (2009): Low-income Latino mothers' booksharing styles and children's emergent literacy development. Early Childhood Research Quarterly, 24, 3, 306-324.

Catts, H. W., Petscher, Y., Schatschneider, C., Sittner Bridges, M., Mendoza K. (2009): Floor effects associated with universal screening and their impact on early identification of reading disabilities. Journal of Learning Disabilities, $42,2,163-176$.

Clark, G. J. (2010): The relationship between handwriting, reading, fine motor and visual-motor skills in kindergarteners. A dissertation submitted to the graduate faculty in partial fulfillment of the requirements for the degree of doctor philosophy. Ames: Iowa State University. Preuzeto: rujan 2016. http://lib.dr.iastate.edu/cgi/viewcontent. cgi? article $=2432 \&$ context $=$ etd

Clasen, L. E. (2016): BookFun - 'There's more to it than reading a book' - Implementing a Danish early literacy programme that supports professionalism, language development and social inclusion. Journal of Early Childhood Literacy, Published online before print May 9, 2016, doi: 10.1177/1468798416638405

Dennis, 1. (2016): The Effects of a Multi-Component Intervention on Preschool Children's Literacy Skills. Topics in Early Childhood Special Education, 36, 1, 15-29.

Denton, CA., Mathes, PG. (2003): Intervention for struggling readers: Possibilities and challenges. U: Foorman, B.R. (ur.) Preventing and remediating reading difficulties: Bringing science to scale (229-251). New York: Timonium, MD.

Early Childhood Education and Care: Next Steps. (2009): Report The Standing Senate Committee on Social Affairs, Science and Technology, Senat of Canada.

Fletcher, J., Lyon, G. R. (1998): Reading: A research-based approach. U W. Evers (ur.): What's gone wrong in America's classrooms? Stanford, CA: Hoover Institute Press.

Florida Birth to Five Early Learning and Developmental Standards. (2011): Preuzetno kolovoz 2016. http://www. floridaearlylearning.com/parents/parent_resources/floridas_early_learning_and_development_standards_birth_ to_five.aspx).

Furnes, B. S. (2010): Predicting Reading and Spelling Difficulties in Transparent and Opaque Orthographies: A Comparison between Scandinavian and U.S./Australian Children. Dyslexia, 16, 2, 119-142.

Gallagher, A., Frith, U., Snowling, M. J. (2000): Precursors of literacy delay among children at genetic risk of dyslexia. Journal of Child Psychology and Psychiatry, 41, 203-213.

Georgiou, G. K., Torppa, M., Manolitsis, G., Lyytinen, H., Parrila, R. (2012): Longitudinal predictors of reading and spelling across languages varying in orthographic consistency. Reading and Writing, 25, 321-346.

Gerde, H. K., Skibbe, L.E., Bowles, R. P., Martoccio T. L. (1992): Child and Home Predictors of Children's Name Writing. Child Development Research, Vol. 2012, Article ID 748532, 12 pages, doi:10.1155/2012/748532.

Goffreda, C. T., Diperna, J. C., Pedersen, J. A. (2009): Preventive screening for early readers: Predictive validity of the Dynamic Indicators of Basic Early Literacy Skills (DIBELS). Psychology in the Schools, 46, 6, 539-552. 
Goswami, U. (2002): Phonology, reading development and dyslexia: A cross-linguistic perspective. Annals of Dyslexia, $52,1-23$.

Greenwood, Ch. R., Abbot, M., Beecher, C., Atwater, J., Petersen, S. (2016): Development, Validation, and Evaluation of Literacy 3D: A Package Supporting Tier 1 Preschool Literacy Instruction Implementation and Intervention. Topics in Early Childhood Special Education. Published online before print June 5, 2016, doi: 10.1177/0271121416652103

Hall, A. H., Simpson, A., Guo, Y., Wang, S. (2015): Examining the Effects of Preschool Writing Instruction on Emergent Literacy Skills: A Systematic Review of the Literature. Clemson: Eugen T. Moore School of Education, Clemson University Tiger Press.

House, L. J., Benton, K., Green, T., Oakley, N., Lemonis, R. (2013): Early Learning Standards for Classrooms Serving Three-Year-Old Children. Mississippi Department of Education. Preuzeto rujan 2016: http://www.earlychildhood. msstate.edu/resources/curriculumforthree/pdfs/els_3.pdf

Ivšac Pavliša, J., Lenček, M. (2011): Fonološke vještine i fonološko pamćenje: neke razlike između djece urednog jezičnog razvoja, djece s perinatalnim oštećenjem mozga i djece s posebnim jezičnim teškoćama kao temeljni prediktor čitanja. Hrvatska revija za rehabilitacijska istraživanja, 47, 1, 1-16.

Johnston, P. H., Rogers, R. (2003): Early Literacy Development: The Case for „Informed Assessment“. U: Neuman, S. B.; Dickinson, D. K. (ur): Handbook of Early Literacy Research (str. 37-389). The Guilford Press. NY.

Justice, L. M., Invernizzi, M. A., Meier, J. D. (2002): Designing and implementing an early literacy screening protocol: Suggestions for the Speech - Language Pathologists. Language, Speech and Hearing Services in Schools, 33, 2, 84-101.

Justice, L. M., Ezell, H. K. (2001): Word and print awareness in 4 year - old children. Child Language Teaching and Therapy, 17, 3, 207-225.

Johnson, C. (2015): Concepts About Print and Literacy Skill Acquisition of Prescool Students. Walden: Walden Dissertations and Doctoral Studies, Walden University.

Kaminski, R. A., Abbott, M., Latimer, K. R., Good, R. H. (2014): The Preschool Early Literacy Indicators - Validity and Benchmark Goals. Topics in Early Childhood Special Education, 34, 2, 71-82.

Kolić-Vehovec, S. (2003): Razvoj fonološke svjesnosti i učenje čitanja: trogodišnje praćenje. Revija za rehabilitacijska istraživanja, 39, 1; 17-32.

Kuvač Kraljević, J., Lenček, M. (2012): Test za procjenjivanje predvještina čitanja i pisanja (PredČiP test). Jastrebarsko: Naklada Slap.

Lenček, M., Ivšac Pavliša, J., Smiljanić, M. (2011:) Preliteracy development: what do we know, what do parents know, what do children know? // Conference proceedings and posters and workshops abstracts of the 3rd Congress of Slovenian logopedists (141-145). Gačnik, M., Strle, M., (ur), 2011, Portorož : Center za korekciju sluha in govora, Aktiv logopedov CKSG.

Lenček, M., Peretić, M., Ivšac Pavliša, J. (2012): Rana pismenost - sto i koliko rano? Third Croatian Symposium on Early Childhood Intervention. Zadar: The University of Zadar.

Lenček, M., Kolundžić, Z., Arapović, D. (2012): Značenje ranog prepoznavanja rizičnih čimbenika u prevenciji teškoća čitanja. Paediatria Croatica. 56, 1, 21-27.

Lenček, M., Kuvač Kraljević, J., Matešić, K. (2012): Vizualni i fonološki aspekt u prepoznavanju slova. Međunarodni znanstveno-stručni skup XVIII. Dani psihologije u Zadru, Penezić, Z., Ćubela Adorić, V. ; Ombla, J. ; Slišković, A. ; Sorić, I.; (ur.). 24.-26.05.2012. Zadar: Sveučilište u Zadru.

Li, H., Rao, N. (2005): Curricular and instructional influences on early literacy attainment: evidence from Beijing,Hong Kong and Singapore. International Journal of Early Years Education, 13, 3, 235-253.

Lonigan, J., Neuman, S., Carta J. (2011): Advancing the measurement of quality for early childhood programs that support early language and literacy outcomes. U: Zaslow, M.; Halle, T.; Martinez-Beck; I.: Measuring quality in early childhood settings. Baltimore: Paul H. Brookes. 
Lust, C. A., Donica, D.K. (2011): Effectiveness of a Handwriting Readiness Program in Head Start: A Two-Group Controlled Trial. Research Scholars Initiative, 65, 5, 560-568.

Lyytinen, H., Erskine, J., Hämäläinen, J., Torppa, M., Ronimus, M. (2015): Dyslexia—Early Identification and Prevention: Highlights from the Jyväskylä Longitudinal Study of Dyslexia. Current Developmental Disorders Reports, 2, 4, 330-338.

Marr, D., Windsor, M.M., Cermak, Sh. (2001): Handwriting Readiness: Locatives and Visuomotor Skills in the Kindergarten Year. Early Childhood Research and Practice: An Internet Journal on the Development, Care, and Education of Young Children, 3 (1) 2-17.

Peretić, M., Padovan, N., Kologranić Belić, L. ( 2015): Rana pismenost. U: Kuvač Kraljević, J. (ur.), Priručnik za prepoznavanje i obrazovanje djece s jezičnim teškoćama (str.52-62). Zagreb: Edukacijsko - rehabilitacijski fakultet Sveučilišta u Zagrebu.

Piasta, S. B., Justice, L., McGinty, A. S., Kaderavek, J. N. (2012): Increasing Young Children's Contact With Print During Shared Reading: Longitudinal Effects on Literacy Achievement. Child Development, 83, 3, 810-820.

Piasta, S. B., Wagner, R. K. (2010): Developing Early Literacy Skills: A Meta-Analysis of Alphabet, Learning and Instruction. Reading Research Quarterly, 45, 1, 8-38.

Pinto, G., Bigozzi, L., Accorti Gamannossi, B., Vezzani, C. (2012): Emergent Literacy and Early Writing Skills. The Journal of Genetic Psychology, 173, 3, 330-354.

Pullen, P.C., Justice, L. (2003): Enhancing Phonological Awareness, Print Awareness, and Oral Language Skills in Preschool Children. Intervention in School and Clinic, 39, 2, 87-98.

Puranik, C. S., Lonigan, C. J. (2011): From Scribbles to Scrabble: Preschool Children's Developing Knowledge of Written Language. Reading and Writing, 24, 5, $567-589$.

Puranik, C., Al Otaiba, S., Sidler, J., Greulich, L. (2014): Exploring the amount and type of writing instruction during language arts instruction in kindergarten classrooms. Reading and Writing, 27, 2, 213-236.

Purcell-Gates, V., Tierney, R. (2009): Public policy brief: Increasing literacy levels of Canadian Students. Preuzeto veljača, 2016. http://cpls.educ.ubc.ca/content/pdfs/LiteracyPolicyBrief.pdf

Powell, D. R., Diamond, K. E., Burchinal, M. R., Koehler, M. J. (2010): Effects of an Early Literacy Professional Development Intervention on Head Stars Teacher and Children. Journal of Educational Psychology, 102, 2 , 299-312.

Puma, M., Bell, S., Cook, R., Heid, C. (2010): Head Start Impact Study. Final Report. Washington, DC: U.S. Department of Health and Human Services, Administration for Children and Families.

Rachmani, R. (2011): The Effects of Phonological Awareness and Alphabet Knowledge Intervention on Four Year Old Kindergarten Children. A thesis submitted in fulfilment of the requirements for the degree of Master of Education at the University of Waikato. Univesity of Waikato. Preuzeto:rujan 2016. http://researchcommons.waikato.ac.nz/ bitstream/handle/10289/5843/thesis.pdf? sequence=3\&isAllowed $=\mathrm{y}$

Scarborough, H. S. (2009): Connecting Early Language and Literacy to Later Reading (Dis)abilities: Evidence, Theory, and Practice. U: Fletcher-Campbell, F.; Soler, J.; Reid, G. (ur): Approaching Difficulties in Literacy Development: Assessment, Pedagogy and Programmes (str. 23-39). SAGE: The Open University, UK.

Schneck, C. M., Amundson, S. J. (2010): Prewriting and handwriting skills. U Case-Smith J.; O’Brien, J. C. (ur.) Occupational therapy for children (6th ed.) (str. 555-580). Maryland Heights, MO: Mosby Elsevier.

Share, D. L., Gur, T. (1999): How Reading Begins: A Study of Preschoolers' Print Identification Strategies. Cognition and Instruction, 17, 2, 177-213.

Sénéchal, M., Pagan, S., Lever, R., Ouellette, G. P. (2008): Relations Among the Frequency of Shared Reading and 4-Year-Old Children's Vocabulary, Morphological and Syntax Comprehension, and Narrative Skills. Early Education and Development, 19, 1, 27-44. 
Smidt, W. K., Lehrl, S., Anders, Y., Pohlmann-Rother, S., Kluczniok, K. (2012): Emergent literacy activities in the final preschool year in the German federal states of Bavaria and Hesse. An International Journal of Research and Development, 32, 3, 301-312.

Soler, J., Miller, L. (2003): The Struggle for Early Childhood Curricula: A comparison of the English Foundation Stage Curriculum, Te Whäriki and Reggio Emilia. International Journal of Early Years Education, 11, 1, 57-68.

Ščapec, K., Kuvač Kraljević, J. (2013): Rana pismenost kod djece s posebnim jezičnim teškoćama (PJT). Hrvatska revija za rehabilitacijska istraživanja, 49, 1, 120-134.

Torppa, M., Poikkeus, A.M., Laakso, M.L., Eklund, K., Lyytinen, H. (2006): Predicting delayed letter name knowledge and its relation to grade 1 reading achievement in children with and without familial risk for dyslexia. Developmental Psychology, 42, 1128-1142.

Torppa, M., Lyytinen, P., Erskine, J., Eklund, K., Lyytinen, H. (2010): Language development, literacy skills and predictive connections to reading in Finnish children with and without familial risk for dyslexia. Journal of Learning Disabilities, 43, 4, 308 - 321.

Vancaš, M. (1999): Jezične sposobnosti kao preduvjet usvajanja čitanja. Doktorska disertacija. Zagreb: Edukacijskorehabilitacijski fakultet Sveučilišta u Zagrebu.

Whitehurst, G. J., Lonigan, C. J. (1998): Child development and emergent literacy. Child Development, 69, 848 - 872.

Wildová R., Kropáčková, J. (2015): Early Childhood Pre-reading Literacy Development. Procedia - Social and Behavioral Sciences, 191, 878 - 883.

Ziegler, J. C., Bertrand, D., Toth, D., Csepe, V., Reis, A., Faisca, L., Saine, N., Lyytinen, H., Vaessen, A., Blomer, L. (2010): Orthographic Depth and Its Impact on Universal Predictors of Reading: A Cross-Language Investigation. Psychological Sciences, 21, 4, 551-9.

\title{
EARLY LITERACY: THE VALUE OF ASSESSMENT
}

\begin{abstract}
Early literacy studies put varying emphasis on the contribution of different components - such as phonological awareness, letter recognition, print concept, spoken language skills, vocabulary knowledge, narrative ability, handwriting, and other predictors - to subsequent achievements in reading and writing as well as overall academic development. In Croatia, there is a lack of systematic research that would longitudinally track the development of these literacy predictor skills and abilities and a scarcity of clear educational preschool curricula that would support these skills crucial for later formal literacy.

Data in the current pilot study was obtained from three- and four-year-old children attending kindergarten using the Early Literacy Assessment questionnaire and the Phonological Awareness and Letter-Naming subtests of the PredČip test, which gathers information regarding the early literacy-skill levels of these children. As expected, the results indicate that older children show more knowledge regarding the concept of print, are more successful on phonological awareness and letter-naming tasks, and exhibit better graphomotor skills. No statistically significant differences between the three-and four-year-olds were found on the group variable emerging reading and writing, which is based on the recognition of features of the written word and prewriting skills. The obtained results were compared with expected achievement and norms in other languages and writing systems to support efforts to establish early literacy assessment criteria and best-practice teaching methods. The components of early literacy that were used in this study -i.e., the print concept, emergent literacy, fine motor skills, phonological awareness, and letter naming - can serve as starting point for screening children who are at risk of developing reading and writing difficulties or dyslexia. Specific findings in the assessed areas that indicate low scores or deviations could be used for the development of intervention programs, for which qualitative analysis of the findings would be necessary. Such qualitative analysis showed that task difficulty or success in various tasks is different for three-year-olds than for four-year-olds. This might imply that there is a nonlinear development of assessed skills, possibly stemming from differing development conditions or from the fact that some skills are formally taught more often than others. Another study, with a greater number of participants and using assessment materials with analyzed psychometric properties, might provide additional insights into early literacy development.
\end{abstract}

Keywords: early literacy, the print concept, phonological awareness, letter knowledge 